
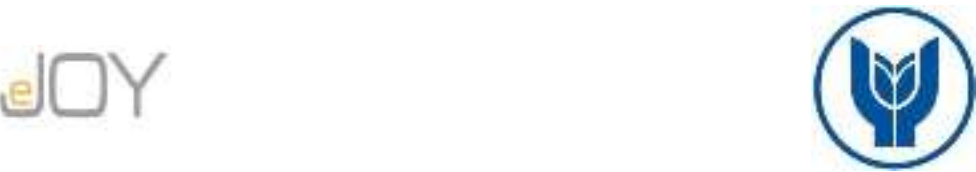

Badurlar, İ. / Journal of Yasar University, 2021, 16/61, 310-329

\title{
Makroekonomik Göstergeler ve Ülke Risk Primi İlişkisinin İncelenmesi: Türkiye Örneği
}

\section{Investigation of Relationship Between Macroeconomic Indicators and Sovereign Risk Premium: Case of Turkey}

\author{
İlkay BADURLAR, Anadolu Üniversitesi, Türkiye, ioner@anadolu.edu.tr \\ Orcid no: 0000-0002-2052-6945
}

Özet: Bu çalışmanın amacı, Türkiye'deki makroekonomik göstergeler/değişkenler ile ülke risk primi arasındaki ilişkiyi incelemektir. Türkiye'nin Ocak 2003 - Haziran 2017 dönemi arasındaki aylık verileri kullanılarak, ülke risk primi ile döviz kuru oynaklı̆̆l, dış borç/ihracat oranı, kısa dönem faiz oranı ve enflasyon oranı arasındaki ilişki Vektör Hata Düzeltme Modeliyle (VECM) incelenmiştir. Sonuçlara göre, Türkiye için, ülke risk primi ile seçilmiş makroekonomik göstergeler/değişkenler arasında uzun dönemli bir nedensellik ilişkisi bulunmamıştır. Ülke risk primi ile kısa dönem faiz oranları dişındaki diğer makroekonomik göstergeler/değişkenler arasında ise kısa dönemli tek yönlü bir nedensellik ilişkisi mevcuttur.

Anahtar Kelimeler: Ülke Risk Primi, Makroekonomik Göstergeler/Değişkenler, Vektör Hata Düzeltme Modeli (VECM)

JEL Sinıflamast: E43, E44, C32

Abstract: The purpose of this study is to examine the relationship between macroeconomic indicators/variables and sovereign risk premium in Turkey. The relationship between sovereign risk premium and exchange rate volatility, external debt/exports ratio, short-term interest rate, inflation rate has been analyzed with the Vector Error Correction Model (VECM) using monthly data for the period between January 2003 - June 2017. Results for Turkey show that there is not a long term causality relationship between sovereign risk premium and selected macroeconomic indicators/variables. When looking at the causality relationship of the short term, that there is one-directional causality between sovereign risk premium and macroeconomic indicators/variables except interest rate.

Keywords: Sovereign Risk Premium, Macroeconomic Indicators/Variables, Vector Error Correction Model

(VECM)

\section{Giriș}

JEL Classification: E43, E44, C32

Ülke riski, borç alan bir egemen devletin yabancı borç verenlere ve/veya yatırımcılara karşı yükümlülüklerini yerine getiremeyebileceği ve/veya karşılayamayabileceği olasılığını ifade eder (Krayenbuehl, 1985). Bu nedenle ülke risk priminin değerlendirilmesi son derece önemlidir. Ülke risk değerlendirmesinin temel işlevi, borcun reddedilme, temerrüde düşme veya devlet borçluları tarafından yapılan ödemeleri geciktirme ihtimalini tahmin etmektir (Burton ve Inoue, 1985). Ülke risk değerlendirmesi, ekonomik, finansal ve politik faktörleri ve bunların belirli bir ülkeyle ilişkili riski belirlemedeki etkileşimlerini değerlendirir. Ülke riskinin belirleyicilerinin algıları önemlidir, çünkü bunlar uluslararası sermaye akımlarının hem arzını hem de maliyetini etkiler (Brewer ve Rivoli, 1990).

Devlet bonolarının getirilerinin hareketliliği oldukça önemli makroekonomik sonuçlar doğurabilir. Devlet bonoları getirilerindeki bir artış eğilimi, hem yatırım hem de tüketim 
kararlarını etkileyen ekonominin geri kalanındaki uzun vadeli faiz oranlarında yaygın bir artışa eşlik eder. Mali tarafta ise yüksek getirili devlet bonoları, daha yüksek borç-servis maliyetlerini içerir ve fonlama maliyetlerini önemli ölçüde artırabilir. Borçlanmanın alışılmadık derecede yüksek maliyetle finanse edilmesi borç döndürme riskinde de bir artışa yol açabilir. Hükümetin fonlama maliyetlerindeki büyük artış, faiz oranlarının üzerindeki bu etkisinin yanı sıra reel ekonomik kayıplara da neden olabilir (Caceres, Guzzo ve Segoviano, 2010).

Gelişmekte olan piyasalara fon sağlayan yatırımcılar için, ülkelerin devlet bonoları getirileri ile ABD bonoları getirileri arasında yaptıkları karşılaştırma yatırımlarının maliyetleri açısından önemli bir göstergedir. Yatırımcılar aynı zamanda ülke risk primini, bir ülkenin ekonomik ve siyasi temellerinin piyasa değerini ölçmek için bir araç ve ülke riskinin bir göstergesi olarak kullanırlar. Aslında, ülke risk primi, devlet borçlanma olasılığı ve borçlanma durumunun iyileşme oranlarının bir fonksiyonudur. Buna ek olarak, ülke risk primi faiz oranı ve kur riskinin yanı sıra, ticari likidite koşulları ve belirli ülke bonolarının yatırımcı tabanındaki değişimler gibi teknik faktörlere bağlıdır (Sy, 2002).

Diğer taraftan gelişmekte olan piyasaların çoğunda, kamu harcamalarını finanse edebilmenin yolu olarak dış finansman kaynakları kullanılmıştır. Yabancı yatırımcılar için ise gelişmekte olan ülkelerin devlet bonoları önemli bir gösterge haline gelmiştir. Bununla beraber yatırım bankaları da ulusal şirketlere sağlayacağı krediler için ülke ekonomisinin sağlamlığını görebilmek amacıyla ülke risk primlerini kullanır olmuştur (Rojas ve Jaque, 2003).

Genel olarak, Olabisi ve Stein (2015), gelişmekte olan ekonomilerin kalıcı makroekonomik istikrarsızlıklara maruz kaldıklarını ve dolayısıyla gelişmiş ekonomilere göre daha yüksek egemen risk primine sahip olduklarını belirtmektedir. Bu nedenle, egemen risk yönetimi açısından, politika yapıcılar için bir ülkenin riskini etkileyen kilit faktörleri kontrol etmek önemlidir.

Finansal piyasalarda, gelişmekte olan ülkelerin risk primi göstergeleri olarak, kredi temerrüt takası (Credit Default Swap) oranı ve EMBI+Ülke Farkı (Emerging Market Bond Index (EMBI)+Country Sovereign Spread) kullanılması yaygın bir uygulamadır. EMBI+ülke farkı bono ihraççısı ülkenin borçlanma maliyetinin, riskten bağımsız bir varlığın faizinden farkını göstermekte ve kredi riskini dolaylı bir şekilde sunmaktadır (Akdoğan ve Chadwick, 2012). CDS primleri ile EMBI+ülke farkındaki artışlar risk algısının arttı̆̆ının bir göstergesidir. 
Günümüzde dünya ekonomisinde meydana gelen krizler özellikle finans ve bankacılık sektörlerinde etki göstermektedir. Dolayısıyla günümüzde ampirik çalışmalar genellikle finans ve bankacılık krizleri ile ülke risk primini ilişkilendirmeye çalışmaktadır (Gerlach vd., 2010). Ancak, son yıllarda ekonomi literatüründe tartışılan bir diğer konu, ülke risk primi ile makroekonomik göstergeler/değişkenler arasındaki ilişkidir ve çalışmaların ülke risk priminin temel belirleyicilerinin analizi üzerine yoğunlaştı̆̆ı görülmektedir. Ayrıca çalışmalarda genellikle ülkelerin risk primi göstergesi olarak kredi temerrüt takası (Credit Default Swap, CDS) primleri kullanılmış ve farklı gelişmişlik düzeyine sahip ülkeler için çok sayıda farklı makroekonomik göstergeler/değişkenler kullanılarak bu göstergelerin/değişkenlerin ülke risk primi üzerindeki etkileri incelenmiştir. Türkiye için yapılan bu çalışmada diğer çalışmalardan farklı olarak ülke risk primi göstergesi olarak CDS primleri yerine EMBI+Ülke Farkı (Emerging Market Bond Index (EMBI)+Country Sovereign Spread) kullanılmıştır. Ocak 2003-Haziran 2017 dönemi verileri kullanılarak Türkiye için yapılan bu çalışma, döviz kuru oynaklığı, dış borç/ihracat oranı, kısa dönem faiz oranı ve enflasyon oranı ile ülke risk priminin göstergesi olarak çalışmaya dâhil edilen EMBI+Türkiye arasındaki çift yönlü nedensellik ilişkisini araştırması bakımından farklılık ve önem taşımaktadır. Türkiye için yapılan diğer çalışmalardan farklı makroekonomik göstergelerin/değişkenlerin ve analiz yönteminin seçilmesi ile çalışmanın özgünlüğü artırılarak literatüre katkı sağlanması amaçlanmıştır.

$\mathrm{Bu}$ amaç kapsamında çalışmanın ikinci kısmında konuya yönelik literatür taramasına, üçüncü kısımda çalışmada kullanılacak veri seti, araştırma yöntemi ve yapılan analiz sonucunda elde edilen ampirik bulgulara yer verilecek, son bölümde ise araştırma sonuçları literatürdeki çalışmalarla karşılaştırılarak değerlendirilecektir.

\section{Literatür Taraması}

Ülke risk primi ile makroekonomik göstergeler/değişkenler arasındaki ilişkiyi inceleyen birçok çalışma yapılmıştır. Söz konusu çalışmalarda farklı makroekonomik göstergelerin/değişkenlerin hem yatay hem de dikey kesitlerde etkileri incelenmiştir. Ülkelerin kredi borçlanma maliyetlerini artıran ülke risk primi üzerinde etkili olan değişkenlerin çoğu bilinse de, bu değişkenlerin ne zaman ve hangi derecede etkili olabileceğini belirlemek oldukça güçtür. Ampirik literatür incelendiğinde, çalışmaların ülke risk primi ile ulusal makroekonomik göstergeler/değişkenler arasındaki ilişkinin araştırılması üzerine yoğunlaştığı görülür. Aynı zamanda bu çalışmaların çoğunluğunda global ve politik faktörlerin ülke risk primi üzerindeki etkileri de incelenmiştir. Tablo 1'de ulusal ve 
uluslararası literatür taraması sonucunda incelenen çalışmaların bir kısmı özetlenmiştir. $\mathrm{Bu}$ özetleme yapılırken çalışmalarda kullanılan makroekonomik göstergeler/değişkenler, ülke risk primi üzerinde önemli etkiye sahip olan ülkelerin likidite durumu, ödeme gücü, temerrüt riski, mali sürdürülebilirlik ve kredi itibarı gibi faktörlerin hangileri için gösterge olduklarına göre sınıflandırılmıştır.

Tablo 1. Ülke Risk Primi İle Makroekonomik Göstergeler/Değişkenler Arasındaki İlişkiyi İnceleyen Literatürdeki Çalıșmalar

\begin{tabular}{|c|c|c|}
\hline $\begin{array}{l}\text { Makroekonomik } \\
\text { Göstergeler/Değişkenler }\end{array}$ & Açıklama & Yazarlar \\
\hline $\begin{array}{l}\text { Kamu Borcu; } \\
\text { Kamu Borcu/GSYİH oranı; } \\
\text { Bütçe açığı/GSYİH; } \\
\text { Mali denge; } \\
\text { Mali denge/GSYİH oranı }\end{array}$ & $\begin{array}{l}\text { Bu değişkenler, borçluların temerrüde } \\
\text { düşmesi için önemli tetikleyici } \\
\text { faktörlerdir ve ülkenin mali } \\
\text { sürdürülebilirliğini ölçerler. Yüksek } \\
\text { kamu borçluluğu, devlet borcunun } \\
\text { temerrüde düşme riskini artırır ve } \\
\text { devlet tahvillerinde daha yüksek } \\
\text { spreadlere dönüşür. Borç alan ülkenin } \\
\text { potansiyel vergi tabanı ne kadar } \\
\text { büyükse, bir hükümetin borcunu geri } \\
\text { ödeme yeteneği de o kadar artar. Bu } \\
\text { değişkenler aynı zamanda siyasi } \\
\text { istikrar seviyesi ve kredi itibarı gibi } \\
\text { diğer önemli faktörler için bir vekil } \\
\text { görevi görebilir. Büyük bir bütçe açığ1, } \\
\text { özel yurtiçi tasarrufları emer ve bir } \\
\text { hükümetin vatandaşlarını cari } \\
\text { harcamaları karşılamak veya borcunu } \\
\text { ödemek için vergilendirme } \\
\text { kabiliyetinden veya iradesinden } \\
\text { yoksun olduğunu gösterir. }\end{array}$ & $\begin{array}{l}\text { Eaton ve Gersovitz, 1981; } \\
\text { Edwards, 1984, 1986; } \\
\text { Cantor ve Packer, 1996; } \\
\text { Cline ve Barnes, 1997; } \\
\text { Eichengreen ve Mody, 1998; } \\
\text { Arora ve Cerisola, 2000; } \\
\text { Goldman Sachs, 2000; } \\
\text { Nogués ve Grandes, 2001; } \\
\text { Ferrucci, 2003; } \\
\text { Canuto vd., 2004; } \\
\text { Çulha vd., 2006; } \\
\text { Hund ve Lesmond, 2008; } \\
\text { Rozada ve Yeyati, 2008; } \\
\text { Baldacci vd., 2008; } \\
\text { Alexopoulou vd., 2009; } \\
\text { Özatay vd., 2009; } \\
\text { Şahinöz ve Gönenç, 2011; } \\
\text { Güler ve Talasli, 2012; } \\
\text { Aizenman vd., 2013; } \\
\text { Csonto ve Ivaschenko, 2013; } \\
\text { Mpapalika ve Malikane, 2019; }\end{array}$ \\
\hline $\begin{array}{l}\text { Brüt rezervler; } \\
\text { Rezervler; } \\
\text { Rezervler/GSMH veya GSYİH } \\
\text { Oranı; } \\
\text { Rezervler/Kısa Vadeli Dış } \\
\text { Borç Oranı; } \\
\text { Rezervler/İthalat Oranı; } \\
\text { Net Dış Varlıklar/GSYİH; }\end{array}$ & $\begin{array}{l}\text { Bir ülkenin sahip olduğu ödeme } \\
\text { gücünü ölçmekte kullanılan } \\
\text { değişkenlerdir. Ülkelerin temerrüde } \\
\text { düşme riskini öncelikle belirleyen } \\
\text { ülkelerin varlıkları ve borçlarının } \\
\text { düzeyidir. Yüksek rezervler, kredi } \\
\text { itibarı, borcu karşılama ve negatif bir } \\
\text { şoku absorbe etme konusunda daha } \\
\text { güçlü bir kabiliyete işaret eder. Bir } \\
\text { ülkenin stok ölçüsü olan GSYİH'nin } \\
\text { yüzdesi olarak diş rezervler, ülkenin } \\
\text { diş borcunu karşılama kapasitesini } \\
\text { gösterir. }\end{array}$ & $\begin{array}{l}\text { Edwards, 1984, 1986; } \\
\text { Cline ve Barnes, 1997; } \\
\text { Eichengreen ve Mody, 1998; } \\
\text { Min, 1998; } \\
\text { Arora ve Cerisola, 2000; } \\
\text { Budina ve Mantchev, 2000; } \\
\text { Mulder ve Perrelli, 2001; } \\
\text { Ferrucci, 2003; } \\
\text { Martell, 2003; } \\
\text { Rowland ve Torres, 2004, } \\
\text { Çulha vd., 2006; } \\
\text { Weigel ve Gemmill, 2006; } \\
\text { Baldacci vd., 2008; } \\
\text { Özatay vd., 2009; } \\
\text { Hilscher ve Nosbusch, 2010; } \\
\text { Güler ve Talasli, 2012; } \\
\text { Aizenman vd., 2013; } \\
\text { Csonto ve Ivaschenko, 2013; } \\
\text { Maltritz, ve Molchanov, 2014; } \\
\text { Hansen ve Zegarra, 2016; } \\
\text { Mpapalika ve Malikane, 2019; }\end{array}$ \\
\hline $\begin{array}{l}\text { Yatırımlar; } \\
\text { Yatırımlar/GSMH } \\
\text { GSYİH Oranı; } \\
\text { Doğrudan Yabancı } \\
\end{array}$ & $\begin{array}{l}\text { Bu değişkenler, ülkenin gelecekteki } \\
\text { büyüme beklentilerini içerir. Daha } \\
\text { yüksek büyüme, ülkelerin likidite } \\
\text { sorunlarını } \\
\text { çözmek }\end{array}$ & $\begin{array}{l}\text { Edwards, 1984, 1986; } \\
\text { Cantor ve Packer 1996; } \\
\text { Cline ve Barnes, 1997; } \\
\text { Eichengreen ve Mody, 1998; }\end{array}$ \\
\hline
\end{tabular}




\begin{tabular}{|c|c|c|}
\hline $\begin{array}{l}\text { Yatırımı; } \\
\text { GSYİH Büyüme Oranı; } \\
\text { Ekonomik Büyüme Oranı; } \\
\text { Kişi Başına Düşen Gelir; } \\
\text { Kişi Başına Düşen GSYİH; } \\
\text { Kişi Başına Düşen GSYİH } \\
\text { Büyümesi; } \\
\text { Endüstriyel Üretim; } \\
\text { Sanayi üretim endeksi; } \\
\text { Ekonomik Kalkınmışlık } \\
\text { Derecesi } \\
\text { (sanayileşmiş/sanayileşmemiş); }\end{array}$ & $\begin{array}{l}\text { kullanabilecekleri rezerv tamponunu } \\
\text { artırır. Ayrıca nispeten yüksek bir } \\
\text { ekonomik büyüme oranı, bir ülkenin } \\
\text { mevcut borç yükünü zaman içinde } \\
\text { ödemesini kolaylaştırır. Ülkeler belirli } \\
\text { bir gelire veya kalkınma düzeyine } \\
\text { ulaştığında, temerrüde düşme } \\
\text { olasılıkları azalabilir. Bir ülkenin } \\
\text { Uluslararası Para Fonu } \\
\text { tarafından sana) } \\
\text { sinıflandırılıp sinıflandırılmadığını } \\
\text { belirten basit bir gösterge değişkeniyle } \\
\text { asgari gelir veya kalkınma düzeyi } \\
\text { temsil edilebilir. }\end{array}$ & $\begin{array}{l}\text { Min, 1998; } \\
\text { Mulder ve Perrelli, 2001; } \\
\text { Goldman Sachs, 2000; } \\
\text { Afonso, 2002; } \\
\text { Nogués ve Grandes, 2001; } \\
\text { Afonso, 2002; } \\
\text { Canuto vd., 2004; } \\
\text { Rowland ve Torres, 2004; } \\
\text { Bissoondoyal ve Bheenick, 2005; } \\
\text { Hund ve Lesmond, 2008; } \\
\text { Şahinöz ve Gönenç, 2011; } \\
\text { Güler ve Talasli, 2012; } \\
\text { Aizenman vd., 2013; } \\
\text { Chowdhury vd., 2013; } \\
\text { Csonto ve Ivaschenko, 2013; } \\
\text { Cristo ve Puig, 2014; } \\
\text { Maltritz, ve Molchanov, 2014; } \\
\text { Clark ve Kassimatis, 2015; } \\
\text { Varlık ve Gebeşoğlu, 2018; } \\
\text { Mpapalika ve Malikane, 2019; }\end{array}$ \\
\hline $\begin{array}{l}\text { Cari hesap dengesi; } \\
\text { Cari işlemler açı̆̆ı veya } \\
\text { fazlası/GSMH veya GSYİH } \\
\text { oranı; }\end{array}$ & $\begin{array}{l}\text { Bir ülkenin ödeme gücünü gösteren } \\
\text { diğer değişkenlerdir. Büyük bir cari } \\
\text { açık, kamu ve özel sektörün birlikte } \\
\text { büyük ölçüde yurt dişından gelen } \\
\text { fonlara güvendiğini gösterir. Cari } \\
\text { hesap dengesi ne kadar düşükse, } \\
\text { ekonomi sermaye girişlerine o kadar } \\
\text { çok bağımlı hale gelir ve uluslararası } \\
\text { fon akışlarındaki tersine dönmeye } \\
\text { karşı daha savunmasız olarak algılanır. } \\
\text { Devam eden cari açılar, zamanla } \\
\text { sürdürülemez hale gelebilecek dış } \\
\text { borçluluğun büyümesine neden olur ve } \\
\text { kredi itibarını düşürür. }\end{array}$ & $\begin{array}{l}\text { Edwards, 1984, 1986; } \\
\text { Cline ve Barnes, 1997; } \\
\text { Min, 1998; } \\
\text { Nogués ve Grandes, 2001; } \\
\text { Ferrucci, 2003; } \\
\text { Canuto vd., 2004; } \\
\text { Baldacci vd., 2008; } \\
\text { Alexopoulou vd., 2009; } \\
\text { Özatay vd., 2009; } \\
\text { Şahinöz ve Gönenç, 2011; } \\
\text { Güler ve Talasli, 2012; } \\
\text { Aizenman vd., 2013; } \\
\text { Csonto ve Ivaschenko, 2013; } \\
\text { Clark ve Kassimatis, 2015; } \\
\text { Varlık ve Gebeşoğlu, 2018; }\end{array}$ \\
\hline $\begin{array}{l}\text { İhracatın büyüme oranı; } \\
\text { İthalatın büyüme oranı; } \\
\text { İhracat/GSYİH oranı; } \\
\text { İthalat/GSMH oranı; } \\
\text { Ticaret hadleri; } \\
\text { Ticarete açılık } \\
\text { (İhracat+İthalat/GSYİH); }\end{array}$ & $\begin{array}{l}\text { Bu değişkenler, ülkelerin dış ödeme } \\
\text { gücünde dış ticaretin önemini gösterir. } \\
\text { Ticarete açıklık; ülkelerin ticarete ve } \\
\text { finansal akışlara açıklık derecesidir. } \\
\text { Genel olarak, açı bir ekonomi, } \\
\text { mevcut borç stokunu yeniden finanse } \\
\text { etmek veya yeni borcu finanse etmek } \\
\text { için gerekli ticaret fazlasını üretebilir. } \\
\text { Ticaret hadleri değişkeni pozitif bir } \\
\text { sayı olduğu için spreadlerle arasında } \\
\text { negatif bir ilişki beklenir. Çünkü bir } \\
\text { ülkenin ihracatının ithalatına göre } \\
\text { daha pahalı hale geldiği anlamına } \\
\text { gelir. }\end{array}$ & $\begin{array}{l}\text { Edwards, 1986; } \\
\text { Min, 1998; } \\
\text { Budina ve Mantchev, 2000; } \\
\text { Goldman Sachs, 2000; } \\
\text { Ferrucci, 2003; } \\
\text { Çulha vd., 2006; } \\
\text { Baldacci vd., 2008; } \\
\text { Alexopoulou vd., 2009; } \\
\text { Hilscher ve Nosbusch, 2010; } \\
\text { Güler ve Talasli, 2012; } \\
\text { Aizenman vd., 2013; } \\
\text { Maltritz, ve Molchanov, 2014; } \\
\text { Hansen ve Zegarra, 2016; }\end{array}$ \\
\hline $\begin{array}{l}\text { D1ş borç; } \\
\text { D1ş borç/GSYİH oranı; } \\
\text { D1ş borç/İhracat oranı; } \\
\text { D1ş borç servisi oranı; } \\
\text { D1ş borç servisi/İhracat oranı; }\end{array}$ & $\begin{array}{l}\text { Bu değişkenler, bir ülkenin zamanlar } \\
\text { arası likidite durumunu gösterir. } \\
\text { Likidite durumu, borçlu ülkenin kısa } \\
\text { vadede borç servisi ödemelerini } \\
\text { gerçekleştirecek finansal varlığının } \\
\text { olup olmadığını ifade etmek için } \\
\text { kullanılır. Daha yüksek bir borç yükü, } \\
\text { daha yüksek bir temerrüt riskine } \\
\text { karşılık gelir ve kredi itibarını düşürür. } \\
\text { Bir ülkenin döviz borcu, döviz } \\
\text { kazançlarına (ihracatına) göre arttıça } \\
\text { yükün ağırlığı artar. Ödeme gücüne }\end{array}$ & $\begin{array}{l}\text { Eaton ve Gersovitz, 1981; } \\
\text { Edwards, 1984, 1986; } \\
\text { Cantor ve Packer 1996; } \\
\text { Cline ve Barnes, 1997; } \\
\text { Eichengreen ve Mody, 1998; } \\
\text { Min, 1998; } \\
\text { Goldman Sachs, 2000; } \\
\text { Arora ve Cerisola, 2000; } \\
\text { Nogués ve Grandes, 2001; } \\
\text { Afonso, 2002; } \\
\text { Ferrucci, 2003; } \\
\text { Canuto vd., 2004; }\end{array}$ \\
\hline
\end{tabular}




\begin{tabular}{|c|c|c|}
\hline & $\begin{array}{l}\text { sahip olduğu hâlde kısa vadede borç } \\
\text { servisi ödemelerini gerçekleştirecek } \\
\text { finansal varlığı bulunmayan borçlu } \\
\text { ülkenin likidite sorunu vardır. }\end{array}$ & $\begin{array}{l}\text { Favero ve Giavazzi, 2004; } \\
\text { Blanchard, 2004; } \\
\text { Rowland ve Torres, 2004; } \\
\text { Çulha vd., 2006; } \\
\text { Hund ve Lesmond, 2008; } \\
\text { Martell, 2008; } \\
\text { Alexopoulou vd., 2009; } \\
\text { Hilscher ve Nosbusch, 2010; } \\
\text { Aizenman vd., 2013; } \\
\text { Chowdhury vd., 2013; } \\
\text { Csonto ve Ivaschenko, 2013; } \\
\text { Cristo ve Puig (2014); } \\
\text { Maltritz, ve Molchanov, 2014; } \\
\text { Hansen ve Zegarra, 2016; }\end{array}$ \\
\hline $\begin{array}{l}\text { Yurtiçi faiz oranı; } \\
\text { Kısa vadeli faiz oranı; }\end{array}$ & $\begin{array}{l}\text { Uzun vadeli devlet tahvili getirileri, } \\
\text { cari ve beklenen kısa vadeli faiz } \\
\text { oranlarının bir fonksiyonudur. Yurt içi } \\
\text { para piyasası likiditesinin göstergesi } \\
\text { olan kısa vadeli faiz oranları, uzun } \\
\text { vadeli likidite koşulları hakkında da } \\
\text { bilgi sağlayabilir. }\end{array}$ & $\begin{array}{l}\text { Eichengreen ve Mody, 1998; } \\
\text { Kamin ve Von Kleist, 1999; } \\
\text { Ferrucci, 2003; } \\
\text { Favero ve Giavazzi, 2004; } \\
\text { Blanchard, 2004; } \\
\text { Moser, 2006; } \\
\text { Alexopoulou vd., 2009; } \\
\text { Hilscher ve Nosbusch, 2010; }\end{array}$ \\
\hline $\begin{array}{l}\text { Döviz kurları; } \\
\text { Döviz kuru istikrarı; } \\
\text { Nominal döviz kuru sepeti; } \\
\text { Reel efektif döviz kuru indeksi; } \\
\text { Reel döviz kurundaki değişim; } \\
\text { Reel efektif döviz kurunun } \\
\text { logaritması; } \\
\text { Ticaret ağırlıklı reel döviz } \\
\text { kurları ortalaması; }\end{array}$ & $\begin{array}{l}\text { Döviz kuru, ulusal paranın yabancı } \\
\text { paralar karşısındaki değerini ifade eder } \\
\text { ve ülkelerin borçlarını ödeyebilme } \\
\text { gücüyle doğrudan ilişkilidir. Döviz } \\
\text { kurundaki yükseliş, ülkenin ulusal } \\
\text { parasının döviz karşısında değer } \\
\text { kaybetmesine bağlı olarak döviz } \\
\text { cinsinden dış borçlarının artmasına yol } \\
\text { açar. Döviz kurunun yükselmesi dış } \\
\text { borç yükünü arttırarak ülkelerin } \\
\text { temerrüde düşme olasılığı ile birlikte } \\
\text { ülke riskini arttırır. Aynı zamanda } \\
\text { döviz kurları, dış rekabet gücünün özel } \\
\text { bir ölçüsüdür. Ayrıca, gelişmekte olan } \\
\text { ülkelerdeki döviz kurundaki } \\
\text { değişmeler dolarizasyon, dış ticaret } \\
\text { hadleri ve geçiş etkisi aracılığıla } \\
\text { enflasyon oranını ciddi şekilde } \\
\text { etkileme gücüne sahiptir. }\end{array}$ & $\begin{array}{l}\text { Edwards, 1986; } \\
\text { Favero vd., 1997; } \\
\text { Min, 1998; } \\
\text { Budina ve Mantchev, 2000; } \\
\text { Goldman Sachs, 2000; } \\
\text { Ferrucci, 2003; } \\
\text { Favero ve Giavazzi, 2004; } \\
\text { Blanchard, 2004; } \\
\text { Rozada ve Yeyati, 2008; } \\
\text { Alexopoulou vd., 2009; } \\
\text { Matsumura ve Vicente, 2010; } \\
\text { Arghyrou ve Tsoukalas, 2011; } \\
\text { Arghyrou ve Kontonikas, 2012; } \\
\text { Csonto ve Ivaschenko, 2013; } \\
\text { Di Cesare vd, 2013; } \\
\text { Varlık ve Gebeşoğlu, 2018; } \\
\text { Mpapalika ve Malikane, 2019; }\end{array}$ \\
\hline Enflasyon oranı & $\begin{array}{l}\text { Enflasyon oranı, bir ülkenin para } \\
\text { politikasını ne kadar iyi yönettiğinin, } \\
\text { ekonomik yönetimin kalitesinin ve } \\
\text { makroekonomik istikrarın bir } \\
\text { göstergesi olarak kullanılır. Yüksek } \\
\text { enflasyon oranı, hükümetin } \\
\text { maliyesindeki yapısal sorunlara işaret } \\
\text { eder ve aşırı borçlanma gibi ihtiyatsız } \\
\text { politikaları ve dolayısıyla daha yüksek } \\
\text { bir temerrüt olasılığını gösterebilir. } \\
\text { Gelişmekte olan ekonomilerde yüksek } \\
\text { enflasyon, ödemeler dengesi } \\
\text { krizlerinin öncü göstergesi olarak } \\
\text { algılanabilir. Ayrıca, enflasyon } \\
\text { oranındaki artış, merkez bankasının } \\
\text { devlet tahvili getirileri üzerinde yukarı } \\
\text { yönlü baskı oluşturabilecek daha sıkı } \\
\text { bir para politikası uygulama olasılığını } \\
\text { artırır. Halkın enflasyonla ilgili } \\
\text { memnuniyetsizliği, }\end{array}$ & $\begin{array}{l}\text { Cantor ve Packer, 1996; } \\
\text { Cline ve Barnes, 1997; } \\
\text { Min, 1998; } \\
\text { Afonso, 2002; } \\
\text { Ferrucci, 2003; } \\
\text { Canuto vd.,2004; } \\
\text { Bissoondoyal ve Bheenick, 2005; } \\
\text { Weigel ve Gemmill, 2006; } \\
\text { Hund ve Lesmond, 2008; } \\
\text { Baldacci vd., 2008; } \\
\text { Alexopoulou vd., 2009; } \\
\text { Güler ve Talasli, 2012; } \\
\text { Aizenman vd., 2013; } \\
\text { Chowdhury vd., 2013; } \\
\text { Csonto ve Ivaschenko, 2013; } \\
\text { Cristo ve Puig, 2014; } \\
\text { Maltritz, ve Molchanov, 2014; } \\
\text { Clark ve Kassimatis, 2015; } \\
\text { Varlık ve Gebeşoğlu, 2018; } \\
\text { Mpapalika ve Malikane, 2019; }\end{array}$ \\
\hline
\end{tabular}




\begin{tabular}{|c|c|c|}
\hline & istikrarsızlığa yol açabilir. & \\
\hline $\begin{array}{l}\text { Ülkenin temerrüt geçmişi; } \\
\text { Borcun yeniden yapılandırılıp } \\
\text { yapılandırılmadığ } 1\end{array}$ & $\begin{array}{l}\text { Diğer değişkenler eşit olduğunda, } \\
\text { yakın geçmişte borcunu ödemeyen bir } \\
\text { ülkenin genel olarak yüksek kredi riski } \\
\text { taşıdığı algılanır ve kredi itibarını } \\
\text { düşürür. }\end{array}$ & $\begin{array}{l}\text { Cantor ve Packer 1996; } \\
\text { Eichengreen ve Mody, 1998; } \\
\text { Afonso, 2002; Hund ve Lesmond, } \\
\text { 2008; Özatay vd., 2009; } \\
\text { Hilscher ve Nosbusch, 2010; } \\
\text { Maltritz, ve Molchanov, 2014; }\end{array}$ \\
\hline
\end{tabular}

Literatüre bakıldığında makroekonomik göstergeler/değişkenlerde meydana gelen değişmelerin ülke risk primi üzerinde önemli derecede etkisinin olduğunu gösteren pek çok çalışma mevcuttur. Ancak, Türkiye için ülke risk priminin belirleyicileri olan makroekonomik göstergeler/değişkenler ile ülke risk primi arasındaki ilişkiyi inceleyen ekonometrik çalışma sayısı sınırlıdır. Türkiye için yapılan çalışmaların genellikle ülke riski şoklarının finans ve bankacılık sistemine etkileri (Varlık, 2017) ile ülke risk priminde gözlenen yapısal şokların makroekonomik etkileri (Varlık ve Gebeşoğlu, 2018) üzerine yoğunlaştı̆̆ı görülmektedir. Ayrıca Türkiye için yapılan çalışmalarda genellikle ülke risk primi göstergesi olarak CDS primleri kullanılmıştır (Yenisu ve Yenice, 2018; Yılmaz ve Ünlü, 2018; Özpınar vd. 2018; Yılmaz ve Çetiner, 2017; Kılcı, 2017; Çonkar ve Vergili, 2017; Danacı vd. 2017; Kar vd. 2016; Şahin ve Altay, 2016). Bu nedenle çalışmada Türkiye'de Ocak 2003- Haziran 2017 döneminde ülke risk primi ile çeşitli makroekonomik değişkenler arasındaki çift yönlü nedensellik ilişkisinin araştırılması ve literatüre katkı sağlanması amaçlanmıştır.

\section{Veri Seti, Yöntem ve Bulgular}

Çalışmaya ait üçüncü bölümde, ilk önce Türkiye için Ocak 2003- Haziran 2017 döneminde ülke risk primi ile seçilmiş makroekonomik göstergeler/değişkenler arasındaki uzun dönem ilişkisi incelenecektir. Çalışmada, literatürdeki diğer çalışmalarda da yararlanılmış olan ülke risk primi üzerinde etkisi olduğu düşünülen dış borç/ihracat oranı (Edwards (1986), Cline ve Barnes, (1997), Arora ve Cerisola (2000), Nogués ve Grandes (2001), Rowland ve Torres, (2004), Martell, (2008) ve Cristo ve Puig (2014)), kısa dönem faiz oranı (Eichengreen ve Mody (1998), Kamin ve Von Kleist (1999), Ferrucci (2003), Moser (2006), Hilscher ve Nosbusch (2010), Favero ve Giavazzi (2004), Blanchard (2004), Alexopoulou vd. (2009)), enflasyon oranı (Cantor ve Packer (1996), Min (1998), Beck (2001), Afonso (2002), Ferrucci (2003), Canuto vd. (2004), Bissoondoyal ve Bheenick (2005), Weigel ve Gemmill (2006), Baldacci vd. (2008), Hund ve Lesmond (2008), Alexopoulou vd, (2009), Güler ve Talasli (2012), Aizenman vd. (2013), Chowdhury vd. (2013), Csonto ve Ivaschenko (2013), Cristo ve Puig (2014), Maltritz, ve Molchanov (2014), Clark ve Kassimatis (2015) ve Mpapalika ve Malikane (2019)) ve döviz kuru oynaklığı (literatürde döviz kuru oynaklığının değişken olarak kullanıldığı bir çalışmaya rastlanmamıştır) makroekonomik değişkenler/göstergeler 
olarak belirlenmiştir. Johansen Eşbütünleşme Testi ile değişkenler arasındaki eşbütünleşme ilişkisi araştırılacaktır. Ülke risk primi ile makroekonomik göstergeler/değişkenler arasındaki kısa dönemli dinamik ilişkiyi araştırırken kullanılacak yöntem ise değişkenler arasında eş bütünleşme ilişkisinin olup olmamasına göre belirlenecektir.

\subsection{Veri Seti}

Çalışmada, modelde yer alan göstergelerin/değişkenlerin Ocak 2003- Haziran 2017 dönemine ait aylık gözlemleri kullanılmıştır. Türkiye'nin ülke risk primini $(E M B I+T R)$ temsil etmek üzere, J. P. Morgan Chase tarafindan geliştirilen ve yaygın olarak gelişmekte olan piyasalarda devlet risk priminin bir göstergesi olarak kabul edilen EMBI+Türkiye indeksi modele dâhil edilmiştir. Bu indeksteki artış, risk algısında bir artışa işaret eder ve Türkiye için risk algısının önemli bir göstergesidir. EMBI+Türkiye indeksi, Türkiye tarafından çıkartılan 10 yıllık ABD Doları cinsine tanımlanmış Hazine tahvillerinin faiz oranı ile ABD Hazinesi tarafından çıkartılan 10 yıllık Hazine tahvillerinin faiz oranı arasındaki farkı gösterir. Çalışmada yer alan döviz kuru oynaklığı $(E X V)$ değişkenini elde etmek için hem dünyada uluslararası ticaret işlemlerinin temel hesap birimi olarak kullanılan hem de Türkiye'deki hane halklarının işlem ve değer muhafaza amacıyla yoğun bir şekilde ellerinde tuttukları ABD Doları kullanılmıştır. Nominal dolar kuru oynaklığını (volatilite) ölçmek için G(ARCH) türü modeller kullanılmış, AR(1) SAR(4) MA(1) SMA(4)-EGARCH(1,1) modeli parametre anlaml1l1klar1 ve model seçim kriterleri dikkate alınarak en uygun model seçilmiş ve modelin koşullu varyansları döviz kuru oynaklığının ölçütü olarak çalışmaya dahil edilmiştir. Çalışmada TC Merkez Bankası'nın gerçekleşen gecelik (1 gecelik işlem) basit faiz oranlarının $(\mathrm{O} / \mathrm{N})$ ağırlıklı ortalamaları, kısa dönem faiz oranlarını (INT) temsil etmektedir. Bir diğer makroekonomik değişken olan dış borç/ihracat oranı $(E D / E X)$, dış borç serisinin ihracat serisine bölünmesi ile elde edilmiştir. Enflasyon oranı (PI) serisi ise Tüketici Fiyatları Endeksi'nin (2003=100) yıllık \% değişim değerlerinden elde edilmiştir. Analizde yer alan nominal dolar kuru oynaklığı $(E X V)$ değişkenini hesaplamak için kullanılan 1 ABD Doları'nın TL karşılığını içeren seri, dış borç $(E D)$, ihracat $(E X)$, TC Merkez Bankası gecelik $(O / N)$ faiz oranları ve Tüketici Fiyatları Endeksi (2003=100) yıllık \% değişim değerleri serileri Türkiye Cumhuriyet Merkez Bankası Elektronik Veri Dağıtım Sistemi'nden, EMBI+Türkiye $(E M B I+T R)$ serisi ise JP Morgan'dan alınmıştır. (ED/EX) serisi dışındaki tüm değişkenlerin doğal logaritması alınmış, serilerin elde edilmesinde ve modelin analizinde EViews 8.1 paket programı kullanılmıştır. 


\subsection{Model}

Türkiye'nin ülke risk primi ile makroekonomik göstergeleri/değişkenleri arasındaki ilişkiyi ortaya koyan model aşağıdaki gibidir:

$L E M B I+T R_{t}=\beta_{0}+\beta_{1} L E X V_{t}+\beta_{2} E D / E X_{t}+\beta_{3} L\left(1+I N T_{t}\right)+\beta_{4} L\left(1+P I_{t}\right)+\varepsilon_{t}$

Modelde $E M B I+T R$; ülke risk primini, $E X V$; döviz kuru oynaklığını, $E D / E X$; dış borç/ihracat oranını, $(1+I N T)$; kısa dönem faiz oranlarını ve $(1+P I)$; enflasyon oranını göstermektedir. Modelde ilişkiyi belirten katsayıların ( $\beta_{1}, \beta_{2}, \beta_{3}$ ve $\left.\beta_{4}\right)$ yönünün pozitif olması beklenmekte; yani döviz kuru oynaklığı, dış borç/ihracat oranı, kısa dönem faiz oranları ve enflasyon oranındaki artışların ülke risk primini artıracağı beklenmektedir. Ayrıca modelde hata terimini gösteren $e_{t}$ 'nin normal dağılıma sahip, ortalamasının sıfır ve varyansının $\sigma_{\varepsilon_{t}}^{2}$ olduğu varsayılmaktadır. Yukarıda yer alan modelden hareketle Türkiye'nin ülke risk primi ile modelde yer alan makroekonomik göstergeler/değişkenler arasındaki ilişsilerin yönü ampirik testler ile belirlenecektir.

\subsection{Birim Kök Testleri}

Serilerin durağan olup olmadıklarını belirlemek amacıyla birim kök testleri yapılır. Gerçekte aralarında bir ilişki bulunmayan değişkenler, seriler durağan olmadığı için birbirleriyle ilişkili gibi görülebilir. Bu durum analizlerde düzmece regresyon sorununun ortaya çıkmasına neden olabilir. Çalışmada zaman serilerinin durağanlık özelliklerini test etmek üzere Genişletilmiş (Augmented) Dickey-Fuller (ADF) (1981) Birim Kök Testi'nden yararlanılmıştır. Tablo 2'de çalışmada kullanılacak zaman serilerinin Genişletilmiş Dickey-Fuller (ADF) Birim Kök Testi Sonuçları yer almaktadır.

Tablo 2. Genişletilmiş Dickey-Fuller (ADF) Birim Kök Testi Sonuçları

\begin{tabular}{cccc}
\hline \hline Değişkenler & & ADF Test İstatistiği & \\
\hline \multirow{2}{*}{ DÜZEY } & Sabit terim içeren & $\begin{array}{c}\text { Sabit ve Trend terimi } \\
\text { içeren }\end{array}$ & $\begin{array}{c}\text { Sabit ve Trend terimi } \\
\text { içermeyen }\end{array}$ \\
\hline \hline \multirow{2}{*}{ LEMBI+TR } & $2,999450(0)$ & $-2,875594(0)$ & $-1,115106(0)$ \\
& {$[-3,610453]$} & {$[-4,211868]$} & {$[-2,625606]$} \\
LEXV & $-3,282088(2)$ & $-3,923887(2)$ & $0,375612(2)$ \\
& {$[-3,661661]$} & {$[-4,284580]$} & {$[-2,641672]$} \\
ED/EX & $-2,817921(1)$ & $-2,847204(1)$ & $-0,902597(1)$ \\
& {$[-3,653730]$} & {$[-4,273277]$} & {$[-2,639210]$} \\
L(1+INT) & $-1,971179(2)$ & $-2,398854(2)$ & $-2,264958(2)$ \\
& {$[-3,621023]$} & {$[-4,226815]$} & {$[-2,628961]$} \\
L(1+PI) & $-3,484653(4)$ & $-3,068224(4)$ & $-1,305083(4)$ \\
& {$[-3,632900]$} & {$[-4,243644]$} & {$[-2,632688]$} \\
\hline \hline BİRINCİ FARK & & & \\
\hline \multirow{2}{*}{$\Delta$ LEMBI+TR } & $-5,191109^{*}(0)$ & $-5,146511 *(0)$ & $-5,158837 *(0)$ \\
& {$[-3,615588]$} & {$[-4,219126]$} & {$[-2,627238]$}
\end{tabular}




$\begin{array}{lccc} & -6,930206^{*}(2) & -6,803544^{*}(2) & -6,974806^{*}(2) \\ \Delta \mathrm{LEXV} & {[-3,670170]} & {[-4,296729]} & {[-2,644302]} \\ & -5,426091^{*}(1) & -5,338194^{*}(1) & -5,528992^{*}(1) \\ \Delta \mathrm{L}(1+\mathrm{INT}) & {[-3,661661]} & {[-4,284580]} & {[-2,641672]} \\ & -4,370328^{*}(1) & -4,368188^{*}(1) & -4,165006^{*}(1) \\ \Delta \mathrm{L}(1+\mathrm{PI}) & {[-3,621023]} & {[-4,226815]} & {[-2,628961]} \\ & -6,830275^{*}(3) & -7,027057^{*}(3) & -6,738394^{*}(3) \\ & {[-3,632900]} & {[-4,243644]} & {[-2,632688]}\end{array}$

( ) içindeki sayılar gecikme uzunluklarını, [ ] içindeki sayılar ise \%1 anlamlılık düzeyindeki MacKinnon (1996) kritik değerlerini gösterir. Schwarz Bilgi Kriteri'ne (SIC) göre gecikme uzunlukları belirlenmiştir. * işareti \%1 anlamlılık düzeyini ifade eder.

ADF test sonuçlarına bakıldığında zaman serilerinin tümü düzeyde birim kök içerirken, birinci farkları alındığında durağan olmakta; yani I(1) özelliği göstermektedir. ADF birim kök testleri eşitlikte sadece sabit terim, sabit terim ve trend terimi ile sabit terim ve trend teriminin olmadığı üç farklı şekilde yapılmış, Tablo 2'in ilgili sütunları incelendiğinde ADF test istatistiklerinin sonuçlarının değişmediği görülmüştür.

\subsection{Eşbütü̈leşme Testi}

Zaman serileri arasında nedensellik araştırılırken hangi yöntemin uygun olacağının belirlenmesinde serilerin eşbütünleşme özellikleri önemlidir. Eşbütünleşme testi, durağan olmayan zaman serileri arasındaki ilişkinin analizini yapar. Eşbütünleşme tekniği kullanmak kısa ve uzun dönem etkilerini birbirinden ayırmaya ve uzun dönem değerlerine doğru ayarlama hızının doğrudan tahmin edilebilmesine olanak tanır (Nişancı, 2005). Çalışmada Johansen'in Eşbütünleşme Testi (1988) kullanılmıştır. Bu test, eşbütünleşme ilişkisinin sayısının ve bu ilişkinin parametrelerinin bulunmasında maksimum olabilirlik yöntemini kullanır. Zaman serileri arasında eşbütünleşme ilişkisinin varlığı durumunda, en az tek yönlü bir nedensellik ilişkisi bulunması gerekir.

Tablo 2'deki ADF test sonuçlarına göre, tüm değişkenler birinci farkları alındığında durağan hale geldikleri için değişkenler arasında eşbütünleşik bir ilişkinin varlığını araştırmak üzere değişkenlere Johansen'in Eşbütünleşme Testi (1988) uygulanmıştır. Bu yöntemde İz Testi ve Maksimum Öz Değer Testi kullanılarak eşbütünleşme ilişkisi araştırılır. Elde edilen maksimum özdeğer ve iz testi istatistikleri kritik değerler ile karşılaştırılarak değişkenler arasında eşbütünleşme ilişkisi olup olmadığına karar verilir.

Öncelikle modelde yer alan değişkenler için bir VAR modeli oluşturulur ve modele ilişkin gecikme sayısı ve hangi modelin verilere uygun olacağı belirlenir. Oluşturulan VAR modeline göre, Son Öngörü Hatası (FPE), Hannan-Quinn Bilgi Kriteri (HQ) ve Akaike Bilgi Kriterine (AIC) göre modelin gecikme sayısı 3'tür. Johansen (1992)'e göre model seçimi yapılarak, en uygun model olarak Model 4 belirlenmiştir. 
Tablo 3 ve Tablo 4'te seçilmiş olan model ile belirlenmiş olan gecikme sayısı kullanılarak yapılan eşbütünleşme testi sonuçları yer almaktadır.

Tablo 3. İz Testi (Trace Test) Sonuçları

\begin{tabular}{lcccr}
$\begin{array}{c}\text { Varsayılan Eşbütünleşme } \\
\text { Eşitliklerinin Sayı1 }\end{array}$ & $\begin{array}{c}\text { Öz Değer } \\
\text { (Eigenvalue) }\end{array}$ & $\begin{array}{c}\text { İz Test } \\
\text { İstatistiği }\end{array}$ & $\begin{array}{c}\text { \%5 Kritik } \\
\text { Değer }\end{array}$ & Olas1lik** $^{* *}$ \\
\hline \hline $\mathrm{H}_{0}: \mathrm{r}=0$ (Sıfir)* & 0,709154 & 140,0571 & 88,80380 & 0,0000 \\
$\mathrm{H}_{0}: \mathrm{r} \leq 1$ (En çok 1)* & 0,668662 & 95,59848 & 63,87610 & 0,0000 \\
$\mathrm{H}_{0}: \mathrm{r} \leq 2$ (En çok 2)* & 0,572886 & 55,83228 & 42,91525 & 0,0016 \\
$\mathrm{H}_{0}: \mathrm{r} \leq 3$ (En çok 3) & 0,455284 & 25,20693 & 25,87211 & 0,0603 \\
$\mathrm{H}_{0}: \mathrm{r} \leq 4$ (En çok 4) & 0,088535 & 3,337270 & 12,51798 & 0,8343 \\
\hline
\end{tabular}

* Boş hipotez reddedilmiştir (\% 5 anlamlılık düzeyine göre).

** Olasılık (p-values) değerlerini gösterir (MacKinnon-Haug-Michelis (1999)'e göre).

Tablo 3 'teki İz testi sonuçlarına göre, değişkenler arasında $\mathrm{H}_{0}: r \leq 3$ (En çok 3 ) ve $\mathrm{H}_{0}: r \leq 4$ (En çok 4) eşbütünleşme ilişkisinin olduğunu iddia eden hipotezler \% 5 anlamlılık düzeyinde reddedilemediğinden değişkenler arasında üç tane eşbütünleşme vektörü mevcuttur.

Tablo 4. Maksimum Öz Değer Testi (Maximum Eigenvalue Test) Sonuçları

\begin{tabular}{lcccr}
$\begin{array}{c}\text { Varsayılan } \\
\text { Eşbütünleşme } \\
\text { Eşitliklerinin Sayıs1 }\end{array}$ & $\begin{array}{c}\text { Öz Değer } \\
\text { (Eigenvalue) }\end{array}$ & $\begin{array}{c}\text { Maksimum Öz } \\
\text { Değer Test } \\
\text { İstatistiği }\end{array}$ & $\begin{array}{c}\text { \%5 Kritik } \\
\text { Değer }\end{array}$ & Olasıllk** $^{* *}$ \\
\hline $\mathrm{H}_{0}: \mathrm{r}=0$ (S1fır)* & 0,709154 & 44,45860 & 38,33101 & 0,0088 \\
$\mathrm{H}_{0}: \mathrm{r} \leq 1$ (En çok 1)* & 0,668662 & 39,76620 & 32,11832 & 0,0048 \\
$\mathrm{H}_{0}: \mathrm{r} \leq 2$ (En çok 2)* & 0,572886 & 30,62536 & 25,82321 & 0,0107 \\
$\mathrm{H}_{0}: \mathrm{r} \leq 3$ (En çok 3)* & 0,455284 & 21,86966 & 19,38704 & 0,0214 \\
$\mathrm{H}_{0}: \mathrm{r} \leq 4$ (En çok 4) & 0,088535 & 3,337270 & 12,51798 & 0,8343 \\
\hline \hline
\end{tabular}

* Boş hipotez reddedilmiştir (\% 5 anlamlılık düzeyine göre).

*** Olasılık (p-values) değerlerini gösterir (MacKinnon-Haug-Michelis (1999)'e göre).

Tablo 4'te yer alan Maksimum Öz Değer testi sonuçlarına göre değişkenler arasında $\mathrm{H}_{0}: \mathrm{r}$ $\leq 4$ (En çok 4) eşbütünleşme ilişkisinin olduğunu iddia eden hipotez ise \% 5 anlamlılık düzeyinde reddedilemediğinden değişkenler arasında dört tane eşbütünleşme vektörü mevcuttur.

Tablo 3 ve Tablo 4'teki sonuçlara göre Ocak 2003- Haziran 2017 döneminde Türkiye’ye ait risk priminin göstergesi olan $(E M B I+T R)$ ile dış borç/ihracat oranı $(E D / E X)$, döviz kuru oynaklığı $(E X V)$, kısa dönem faiz oranları $(1+I N T)$ ve enflasyon oranı $(1+P I)$ arasında uzun dönemli denge ilişkisi söz konusudur. Bu sonuçlara göre dış borç/ihracat oranı, döviz kuru oynaklığı, kısa dönem faiz oranları, enflasyon oranı ve ülke risk priminin göstergesi olan $(E M B I+T R)$ uzun dönemde beraber hareket etmektedir. 


\subsection{Vektör Hata Düzeltme Modeli (VECM)}

Granger (1988) değişkenler arasında eşbütünleşme ilişkisinin varlığı durumunda, dinamik etkilerin araştırılmasında Vektör Otoregresif Modeli (VAR)'nin yerine Vektör Hata Düzeltme Modeli (VECM)'nin kullanılmasının uygun olacağını belirtmiştir. VECM'e göre, bağımlı değişkendeki değişimler, açıklayıcı değişkenlerdeki değişmenin ve eşbütünleşik regresyondaki gecikmeli hata teriminin bir fonksiyonudur. VECM, değişkeler arasındaki uzun dönem dengesi ile kısa dönem dinamikleri arasında ayrım yapmaya ve kısa dönem dinamiklerinin belirlenmesine imkân tanımaktadır. $\mathrm{Bu}$ amaçla, durağan olmayan değişkenlerin birinci dereceden farkları alınarak, açıklayıcı değişkenler arasına uzun dönemli dengeye uyumlaşmayı yansıtan bir hata düzeltme terimi eklenmektedir. Değişkenler arasında eşbütünleşme ilişkisinin varlığı durumda, en az bir yönlü nedensellik ilişkisinin bulunması gerekmektedir.

Seçilen makroekonomik göstergeler/değişkenler ile ülke risk primi $(E M B I+T R)$ arasındaki kısa dönemli dinamik ilişkileri belirlemek üzere kurulan Vektör Hata Düzeltme Modelleri aşağıda yer almaktadır:

$$
\begin{aligned}
\Delta L E M B I+T R_{t} & =\beta_{0}+\sum_{i=1}^{n} \beta_{1 i} \Delta L E M B I+T R_{t-i}+\sum_{i=1}^{n} \beta_{2 i} \Delta L E X V_{t-i} \\
& +\sum_{i=1}^{n} \beta_{3 i} \Delta E D / E X_{t-i}+\sum_{i=1}^{n} \beta_{4 i} \Delta L I N T_{t-i}+\sum_{i=1}^{n} \beta_{5 i} \Delta L P I_{t-i}+\beta_{6} E C T_{t-1}+\varepsilon_{t} \\
\Delta L E X V_{t}=\beta_{7}+ & \sum_{i=1}^{n} \beta_{8 i} \Delta L E X V_{t-i}+\sum_{i=1}^{n} \beta_{9 i} \Delta L E M B I+T R_{t-i}+\sum_{i=1}^{n} \beta_{10 i} \Delta E D / E X_{t-i} \\
& +\sum_{i=1}^{n} \beta_{11 i} \Delta L I N T_{t-i}+\sum_{i=1}^{n} \beta_{12 i} \Delta L P I_{t-i}+\beta_{13} E C T_{t-1}+\varepsilon_{t} \\
\Delta E D / E X_{t}=\beta_{14} & +\sum_{i=1}^{n} \beta_{15 i} \Delta E D / E X_{t-i}+\sum_{i=1}^{n} \beta_{16 i} \Delta L E M B I+T R_{t-i}+\sum_{i=1}^{n} \beta_{17 i} \Delta L E X V_{t-i}(4) \\
& +\sum_{i=1}^{n} \beta_{18 i} \Delta L I N T_{t-i}+\sum_{i=1}^{n} \beta_{19 i} \Delta L P I_{t-i}+\beta_{20} E C T_{t-1}+\varepsilon_{t} \\
& +\sum_{i=1}^{n} \beta_{22 i} \Delta L I N T_{t-i}+\sum_{i=1}^{n} \beta_{23 i} \Delta L E M B I+T R_{t-i}+\sum_{i=1}^{n} \beta_{24 i} \Delta L E X V_{t-i} \\
& +\sum_{i=1}^{n} \beta_{25 i} \Delta E D / E X_{t-i}+\sum_{i=1}^{n} \beta_{26 i} \Delta L P I_{t-i}+\beta_{27} E C T_{t-1}+\varepsilon_{t}
\end{aligned}
$$




$$
\begin{aligned}
\Delta L P I_{t}=\beta_{28} & +\sum_{i=1}^{n} \beta_{29 i} \Delta L P I_{t-i}+\sum_{i=1}^{n} \beta_{30 i} \Delta L E M B I+T R_{t-i}+\sum_{i=1}^{n} \beta_{31 i} \Delta L E X V_{t-i} \\
& +\sum_{i=1}^{n} \beta_{32 i} \Delta E D / E X_{t-i}+\sum_{i=1}^{n} \beta_{33 i} \Delta L I N T_{t-i}+\beta_{34} E C T_{t-1}+\varepsilon_{t}
\end{aligned}
$$

Denklemlerde t; zamanı, n; gecikme sayısını, $\Delta$; fark terimini, $\varepsilon_{t}$; otokorelasyonlu olmayan hata terimlerini, $E C T_{t-1}$ hata düzeltme teriminin bir gecikmeli değerini gösterir. $\beta_{6}, \beta_{13}, \beta_{20,} \beta_{27}$ ve $\beta_{34}$ ise sirayla $\triangle L E M B I+T R, \triangle L E X V, \triangle E D / E X, \triangle L I N T$ ve $\triangle L P I ' n ı n$ uzun dönemdeki ilişkisini gösteren hata düzeltme terimlerinin bir gecikmeli katsayılarını gösterir. Bu katsayılar bağımlı değişken ile bağımsız değişkenlerin denge ilişkisine geri dönme hızını gösterirler. $\triangle L E M B I+T R_{t-i}, \Delta L E X V_{t-i}, \Delta E D / E X_{t-i}, \Delta L I N T_{t-i}$ ile $\Delta L P I_{t-i}$ kısa dönem dinamikleri, önlerinde yer alan katsayılar ise kısa dönem ilişkilerini yansıtır.

VECM'de önemli olan kısa ve uzun dönemli nedensellik ilişkileri arasındaki farkı birbirinden ayırmaktır. Love ve Chandra (2005), hata düzeltme teriminin uzun dönemli nedensel etkileri, bağımsız değişkenlerdeki gecikme değerlerinin ise kısa dönemli nedensel etkileri gösterdiğini belirtmiştir. Granger (1988)'e göre VECM yardımıyla nedensellik iki şekilde değerlendirilir:

1) $E C T_{t-1}$ katsayısının negatif ve istatistiksel açıdan anlamlı olması eşbütünleşik seriler arasındaki kısa dönemli sapmaların uzun dönemde ortadan kalktığını ve serilerin uzun dönemde birlikte dengeye geldiklerini gösterir. Yani, $E C T_{t-1}$ katsayısı negatif işaretli ve istatiksel açıdan anlamlıysa bağımsız değişkenlerden bağımlı değişkene doğru uzun dönemli bir nedensellik vardır.

2) Her bir bağımsız değişkenin gecikmeleri toplanarak, bu toplama blok şeklinde Wald $\left(\chi^{2}\right)$ Testinin uygulanması ile değişkenler arasındaki kısa dönemli nedensellik ilişkisi araştırılır.

Ocak 2003- Haziran 2017 dönemi için ülke risk primi $(E M B I+T R)$, döviz kuru oynaklığ $(E X V)$, dış borç/ihracat oranı $(E D / E X)$, kısa dönem faiz oranları $(1+I N T)$ ve enflasyon oranına $(1+P I)$ ait seriler ile (2), (3), (4), (5) ve (6) no.lu her bir denklem VECM ile tahmin edilmiştir. Akaike Bilgi Kriterine (AIC) göre gecikme sayısı 3 olarak belirlenmiştir. Denklemlerde yer alan $E C T_{t-1}$ hata terimi katsayılarının işaretlerine ve anlamlılıklarına bakarak uzun dönem nedensellik ilişkisi araştırılmış, makroekonomik değişkenler/göstergeler ile ülke risk primi $(E M B I+T R)$ arasında kısa dönemli nedensellik ilişkisi Block Exogeneity Wald Testi aracılığıyla VEC Granger anlamında test edilmiştir. Tablo 5'te VECM ile tahmin edilen (2), 
(3), (4), (5) ve (6) no.lu denklemlerde yer alan $E C T_{t-1}$ hata terimi katsayıları ve her bir bağımsız değişkenin gecikmelerinin toplamına blok şeklinde uygulanan Wald $\left(\chi^{2}\right)$ testi sonuçları verilmiştir. Tablo 6'da ise Tablo 5'teki sonuçlara göre ortaya çıkan nedensellik ilişkileri özet şekilde yer almaktadır.

Tablo 5. VECM'e Dayalı Nedensellik Testlerine İlişkin Sonuçlar

\begin{tabular}{|c|c|c|c|c|c|c|}
\hline \multirow[t]{2}{*}{$\begin{array}{l}\text { Bağımlı } \\
\text { Değişken }\end{array}$} & \multicolumn{6}{|c|}{ Bağımsız Değişkenler } \\
\hline & $\begin{array}{c}\Delta \mathrm{LEMBI}+\mathrm{TR} \\
\left.\left(\chi^{2}\right) \text { test } i\right)\end{array}$ & $\begin{array}{l}\Delta \mathrm{LEXV} \\
\left(\chi^{2} \text { testi) }\right.\end{array}$ & $\begin{array}{l}\Delta \mathrm{ED} / \mathrm{EX} \\
\left(\chi^{2} \text { testi) }\right.\end{array}$ & $\begin{array}{c}\Delta \mathrm{LINT} \\
\left(\chi^{2} \text { testi) }\right.\end{array}$ & $\begin{array}{c}\Delta \mathrm{LPI} \\
\left(\chi^{2} \text { testi) }\right.\end{array}$ & $\mathrm{EC}_{\mathrm{t}-1}$ \\
\hline$\triangle \mathrm{LEMBI}+\mathrm{TR}$ & - & $\begin{array}{c}15,43104 * \\
(0,0015)\end{array}$ & $\begin{array}{c}9,591992 * \\
(0,0224)\end{array}$ & $\begin{array}{c}4,988375 \\
(0,1727)\end{array}$ & $\begin{array}{c}10,91176^{*} \\
(0,0122)\end{array}$ & $\begin{array}{c}0,662765^{*} \\
(0,0036)\end{array}$ \\
\hline$\triangle \mathrm{LEXV}$ & $\begin{array}{r}4,739127 \\
(0,1919)\end{array}$ & - & $\begin{array}{c}7,634541 \\
(0,0542)\end{array}$ & $\begin{array}{c}2,646556 \\
(0,4494)\end{array}$ & $\begin{array}{c}6,087349 \\
(0,1074)\end{array}$ & $\begin{array}{c}1,962307 \\
(0,0721)\end{array}$ \\
\hline$\Delta \mathrm{ED} / \mathrm{EX}$ & $\begin{array}{c}3,994710 \\
(0,2620)\end{array}$ & $\begin{array}{c}5,938964 \\
(0,1146)\end{array}$ & 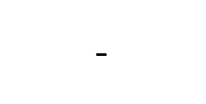 & $\begin{array}{c}8,817945^{*} \\
(0,0318)\end{array}$ & $\begin{array}{c}10,70458^{*} \\
(0,0134)\end{array}$ & $\begin{array}{c}6,65 \mathrm{E}-05^{*} \\
(0,0395)\end{array}$ \\
\hline$\Delta \mathrm{LINT}$ & $\begin{array}{c}3,259884 \\
(0,3533)\end{array}$ & $\begin{array}{c}1,149993 \\
(0,7650)\end{array}$ & $\begin{array}{c}2,054775 \\
(0,5611)\end{array}$ & - & $\begin{array}{c}5,451539 \\
(0,1416)\end{array}$ & $\begin{array}{c}-0,000207 \\
(0,9872)\end{array}$ \\
\hline$\Delta \mathrm{LPI}$ & $\begin{array}{c}1,226643 \\
(0,7466) \\
\end{array}$ & $\begin{array}{c}0,101264 \\
(0,9917)\end{array}$ & $\begin{array}{c}2,921555 \\
(0,4039) \\
\end{array}$ & $\begin{array}{c}2,031581 \\
(0,5659) \\
\end{array}$ & - & $\begin{array}{c}0,176377 \\
(0,5598)\end{array}$ \\
\hline
\end{tabular}

( ) içindeki değerler olasıllık değerlerini gösterir.

* Nedensellik ilişkisinin olmadığını iddia eden boş hipotezin \%5 anlamlılık düzeyinde reddedildiğini gösterir.

Tablo 5'teki sonuçlar değerlendirildiğinde; ülke risk priminin $(E M B I+T R)$ bağımlı değişken olduğu modelde değişkenler arasındaki uzun dönemli nedensellik ilişkisinin göstergesi olan $E C T_{t-1}$ hata terimi katsayısı istatiksel olarak anlamlı olmasına rağmen, negatif değer taşımadığı için ülke risk primi ile makroekonomik değişkenler arasında uzun dönemli bir nedensellik ilişkisi yoktur. Aynı şekilde dış borç/ihracat oranı (ED/EX) değişkeninin yer aldığı modelde de $E C T_{t-1}$ hata terimi katsayısı istatiksel olarak anlamlı olmasına rağmen, negatif değer taşımadığı için değişkenler arasında uzun dönemli bir nedensellik yoktur. Diğer makroekonomik değişkenlerin bağımlı değişken olarak yer aldığı modellerde ise hem $E C T_{t-1}$ hata terimi katsayısı istatiksel olarak anlamlı değil, hem de negatif işaret taşımamaktadır. Dolayısıyla bu değişkenler arasında da uzun dönemli bir nedensellik ilişkisi bulunmamaktadır. 
Tablo 6. Kısa Dönem Nedensellik Analizi Sonuçları

\begin{tabular}{lc} 
Nedenselliğin yönü & Nedensellik İlişkisi \\
\hline \hline $\mathrm{EXV} \Longrightarrow$ EMBI+TR & VAR \\
$\mathrm{ED} / \mathrm{EX} \Longrightarrow$ EMBI+TR & VAR \\
$\mathrm{INT} \Longrightarrow \mathrm{EMBI+TR}$ & YOK \\
$\mathrm{PI} \Rightarrow \mathrm{EMBI+TR}$ & VAR \\
\hline $\mathrm{EMBI}+\mathrm{TR} \Rightarrow \mathrm{EXV}$ & YOK \\
$\mathrm{EMBI}+\mathrm{TR} \Rightarrow \mathrm{ED} / \mathrm{EX}$ & YOK \\
$\mathrm{EMBI}+\mathrm{TR} \Rightarrow \mathrm{INT}$ & YOK \\
$\mathrm{EMBI}+\mathrm{TR} \Rightarrow \mathrm{PI}$ & YOK
\end{tabular}

$\Rightarrow$ Nedensellik ilişkisinin yönünü göstermektedir.

Tablo 6'da, Tablo 5'deki $\left(\chi^{2}\right)$ istatistikleri ve olasılık $(\rho)$ değerlerine göre; ülke risk primi $(E M B I+T R)$ ile makroekonomik göstergeler/değişkenler arasındaki kısa dönemli nedensellik ilişkileri analizinin özeti yer almaktadır. Tablo 5'deki $\left(\chi^{2}\right)$ istatistikleri ve olasılık $(\rho)$ değerlerine göre; ülke risk primi $(E M B I+T R)$ ile kısa dönem faiz oranları (INT) dışındaki diğer makroekonomik göstergeler/değişkenler arasında kısa dönemli bir nedensellik ilişkisi mevcuttur. Yani, çalışmada yer alan döviz kuru oynaklığı $(E X V)$, dış borç/ihracat oranı $(E D / E X)$, ve enflasyon oranı $(P I)$ değişkenlerinin her biri ülke risk primindeki $(E M B I+T R)$ değişmelere Granger anlamında neden olmaktadır. Buna göre, ülke risk primi $(E M B I+T R)$ makroekonomik göstergelerin/değişkenlerin şimdiki ve geçmişteki değerlerinden etkilenmektedir. Ülke risk priminden $(E M B I+T R)$ makroekonomik göstergelere/değişkenlere doğru kısa dönemli nedensellik ilişkisine bakıldığında ise; kısa dönemli bir nedensellik ilişkisine bulunamamıştır.

\section{Sonuç}

Ocak 2003- Haziran 2017 dönemine ait aylık verilerin kullanıldığı bu çalışmada, Türkiye için ülke risk priminin belirleyicileri olan makroekonomik göstergeler/değişkenler ile ülke risk primi arasında kısa ve uzun dönem ilişkisi araştırılmıştır. Çalışmada kullanılmak üzere seçilmiş makroekonomik göstergeler/değişkenler; döviz kuru oynaklığı, dış borç/ihracat oranı, kısa dönem faiz oranı ve enflasyon oranıdır. Johansen Eşbütünleşme Testi kullanılarak bu makroekonomik göstergeler/değişkenler ile ülke risk primi arasındaki uzun dönem ilişkisi araştırılmıştır. Eşbütünleşme testi sonuçlarına göre ülke risk primi ile makroekonomik göstergeler/değişkenler arasında bir uzun dönem ilişkisi mevcuttur. Seçilen makroekonomik göstergeler/değişkenler ile ülke risk primi arasındaki dinamik ilişki ise Vektör Hata Düzeltme Yöntemi (VECM) kullanılarak araştırılmıştır. VECM kullanılarak yapılan nedensellik testlerinin sonuçlarına göre ise ülke risk primi $(E M B I+T R)$ ile çalışmada yer alan makroekonomik göstergeler/değişkenler arasında uzun dönemli bir nedensellik ilişsisi yoktur. 
Ülke risk primi $(E M B I+T R)$ ile kısa dönem faiz oranı $(I N T)$ dışındaki diğer makroekonomik göstergeler/değişkenler arasında ise kısa dönemli bir nedensellik ilişkisi mevcuttur. Diğer bir ifade ile döviz kuru oynaklığı $(E X V)$, dış borç/ihracat oranı $(E D / E X)$ ve enflasyon oranı $(P I)$ değişkenleri ülke risk primindeki $(E M B I+T R)$ değişmelerin nedenidir. Bu sonuç, kısa dönem faiz oranı hariç çalışmada ele alınan diğer makroekonomik göstergelerde/değişkenlerde meydana gelen bir değişmenin ülke risk primi üzerinde etkili olduğunu ortaya koymaktadır.

Elde edilen sonuçlar literatürdeki diğer sonuçlarla karşılaştırıldığında genel olarak literatüre uyumlu olduğu görülmektedir. Çalışmada dış borç/ihracat oranı ile ülke risk primi arasındaki ilişkiye ait elde edilen sonuç, literatürdeki çalışmalarda elde edilen dış borç/ihracat oranının $(E M B I+T R)^{\prime}$ yi etkilediği sonucunu desteklemektedir. Yine enflasyon oranı ile ülke risk primi arasındaki ilişkiye ait elde edilen sonuç, enflasyonun ülke risk priminin önemli bir belirleyicisi olmadığı sonucunu elde eden Weigel ve Gemmill (2006)'in çalışması hariç literatürdeki diğer çalışmalar ile uyumludur. Literatürde döviz kurlarını temsil etmek üzere farklı değişkenlerin kullanıldığı pek çok çalışma bulunmakla birlikte döviz kuru oynaklığının değişken olarak kullanıldığı bir çalışmaya rastlanmamıştır. Çalışmaların hemen hepsinde döviz kuru ile ülke risk primi arasında pozitif bir ilişki olduğu sonucunun elde edildiği görülmektedir. Sadece Budina ve Mantchev (2000) reel efektif döviz kuru indeksi ile ülke risk primi arasında negatif bir ilişski olduğu sonucunu elde ederken, Mpapalika ve Malikane (2019), döviz kurunun ülke risk primi üzerinde önemsiz olduğunu bulmuşlardır. Çalışmada hem kısa dönem faiz oranından ülke risk primine hem de ülke risk biriminden kısa vadeli faiz oranına doğru bir nedensellik ilişkisi bulunmamıştır. Literatürdeki çalışmalarda ise Kamin ve Von Kleist (1999), Ferrucci (2003), Hilscher ve Nosbusch (2010) Favero ve Giavazzi (2004), Blanchard (2004), Alexopoulou vd. (2009) faiz oranları ve ülke risk primi arasında pozitif bir ilişki bulurken; Eichengreen ve Mody (1998) ve Moser (2006) negatif bir ilişki bulmuşlardır.

$E M B I+T R$ 'deki yükseliş Türkiye'ye ait ülke risk primini ve Türkiye'ye ilişkin risk algısını artırmakta, bu durum Türkiye'ye yönelik sermaye akımlarını yavaşlatmaktadır. Buna karşılık, $E M B I+T R$ düştüğünde Türkiye'ye ilişkin risk algısında ve ülke risk priminde azalış meydana gelmektedir. Bu durumda ise Türkiye'ye yönelen sermaye akımları hız kazanmaktadır. Ülke risk priminin makroekonomik göstergelerin/değişkenlerin şimdiki ve geçmişteki değerlerinden etkilendiği sonucundan yola çıkarak; Türkiye'nin ülke risk primindeki yükselişleri sınırlı tutacak biçimde ülke risk primi üzerinde etkili olan makroekonomik değişkenlerde istikrarı sağlayıcı politikalar uygulaması son derece önemlidir. Bununla beraber makroekonomik göstergelerle/değişkenlerle ülke risk primini açıklayabilmek her zaman mümkün olmayabilir. Makroekonomik değişkenlerde oynamalar olmadığı dönemlerde bile, 
hem ülke içi siyasi belirsizlikler hem de diş âlemde meydana gelen değişimler ülke risk primini etkileyebilmektedir. Genel olarak bakıldığında, sağlam makroekonomik politikalar ve ülke risk yönetimi politikaları uygulayan ve güçlü mali kurumları olan ülkeler, daha düşük ülke riski yaşamaktadır. 


\section{KAYNAKÇA}

Afonso, A. 2002. "Understanding the Determinants of Government Debt Ratings: Evidence for the Two Leading Agencies", Available at SSRN 300785. 1-29.

Aizenman, J., Jinjarak, Y. and Park, D. 2013. "Fundamentals and Sovereign Risk of Emerging Markets", NBER Working Paper, 18963.

Akdoğan, K. and Chadwick, M.G. 2012. “CDS-Bono Fark1 ve Düzeltme Hareketi”, Türkiye Cumhuriyet Merkez Bankası Ekonomi Notlarl, 1, 1-9,

Alexopoulou, I., Bunda, I. and Ferrando, A. 2009. "Determinants of Government Bond Spreads in New EU Countries", ECB Working Paper, No. 1101.

Arghyrou, M.G. and Tsoukalas, J. 2011. "The Greek Debt Crisis: Likely Causes, Mechanics and Outcomes", The World Economy, 34, 173-191.

Arghyrou, M.G. and Kontonikas, A. 2012. "The EMU Sovereign Debt Crisis: Fundamentals, Expectations and Contagion" Journal of International Financial Markets, Institutions and Money, 22, 658-677.

Arora, V. and Cerisola, M. 2000. "How does US Monetary Policy Influence Economic Conditions in Emerging Markets?", International Monetary Fund, 0-148.

Badurlar Öner, İ. 2008. "Türkiye'de Konut Fiyatları İle Makro Ekonomik Değişkenler Arasındaki İlişkinin Araştırılması", Anadolu Üniversitesi Sosyal Bilimler Dergisi, Cilt:8, Sayı:1, 223-238.

Baldacci, E., Gupta, S. and Mati, A. 2008. "Is it (still) Mostly Fiscal? Determinants of Sovereign Spreads in Emerging Markets", IMF Working Papers, 1-23.

Blanchard, O. 2004. "Fiscal Dominance and İnflation Targeting: Lessons From Brazil", NBER Working Paper No. 10389.

Bissoondoyal-Bheenick, E. 2005. "An Analysis of the Determinants of Sovereign Ratings", Global Finance Journal, 15(3), 251-280.

Brewer, T. L. and Rivoli, P. 1990. "Politics and Perceived Country Creditworthiness in International Banking". Journal of Money, Credit and Banking, 22(3), 357-369.

Budina, N. and Mantchev, T. 2000, "Determinants of Bulgarian Brady Bond Prices: An Empirical Assessment", World Bank Working Paper, No. WPS 2277, Washington D.C.

Burton, F. N. and Inoue, H. 1985. "An Appraisal of the Early-Warning Indicators of Sovereign Loan Default in Country Risk Evaluation Systems”, Management International Review, 25(1), 45-56.

Caceres, C., Guzzo, V. and Segoviano Basurto, M. 2010. "Sovereign Spreads: Global Risk Aversion, Contagion or Fundamentals?", IMF Working Papers, 1-29.

Cantor, R. and Packer, F. 1996. "Determinants and Impact of Sovereign Credit Ratings", Economic Policy Review, 2(2). 37-54.

Canuto, O., Santos P. F. and S Porto, P. C. 2004. "Macroeconomics and Sovereign Risk Ratings". World Bank Discussion Papers, Washington D. C., 1-19.

Chowdhury, S.M.Z.I., Bayar, Y. and Kılıç, C. 2013.” Effects of Major Macroeconomıc Indicators on Emergıng Markets Bond Index", Afyon Kocatepe Üniversitesi, IIBF Dergisi, (C. XV, S. II, 2013).

Clark, E. and Kassimatis, K. 2015. "Macroeconomic Effects On Emerging-Markets Sovereign Credit Spreads." Journal of Financial Stability, 20, 1-13.

Cline, W.R. and Barnes, K.J.S. 1997. "Spreads and Risk in Emerging Market Lending”. IIF Research Paper, No. $97-1$.

Cristo, M. and Puig, M. 2004. "Dollarization and the Relationship Between EMBI and Fundamentals Latin American Countries", Institut de Recerca en Economia Aplicada Regional i Publica Research Institute of Applied Economics Working Paper, (6): 1-37.

Çulha, O. Y., Özatay, F. and Şahinbeyoglu, G. 2006. "The Determinants of Sovereign Spreads in Emerging Markets", CBRT Working Paper, 06/04, 1-43.

Di Cesare, A., Grande, G., Manna, M. and Taboga, M. 2013. "Recent Estimates of Sovereign Risk Premia For Euro-Area Countries", Questioni di Economia e Finanza (Occasional Papers), Bank of Italy, Economic Research and International Relations Area, No 128.

Edwards, S. 1984. "LDC Foreign Borrowing and Default Risk: An Empirical Investigation, 1976- 80", American Economic Review, Vol. 74, Issue 4, 726-34.

Edwards, S. 1986. "The Pricing of Bonds and Bank Loans in International Markets. An Empirical Analysis of Developing Countries' Foreign Borrowing”, European Economic Review, Vol. 30, No. 3, 565-589.

Eichengreen, M. and Mody, A. 1998. "What Explains Changing Spreads on Emerging-Market Debt: Fundamentals or Market Sentiment?", Working Paper, No. 6408, National Bureau of Economic Research.

Favero, C. A., Giavazzi, F. and Spaventa, L. 1997. "High Yields: The Spread on German Interest Rates", Economic Journal, 1997, Vol. 107, Issue 443, 956-85.

Favero, C. A. and Giavazzi, F. 2004. "Inflation Targeting and Debt: Lessons From Brazil”, NBER Working Paper No. 10390. 
Ferrucci, G. 2003. "Empirical Determinants of Emerging Market Economies' Sovereign Bond Spreads", Bank of England Working Paper, 205, 1-42.

Gerlach, S., Schulz, A. and Wolff, G. B. 2010. "Banking and Sovereign Risk in the Euro Area", CEPR Discussion Paper, No. 7833.

Goldman Sachs, 2000. "Introducing GS-ESS: A New Framework for Assessing Fair Value in Emerging Markets Hard-Currency Debt" Goldman Sachs Global Economics Paper, No:45.

Granger, C.W.J. 1988. "Some Recent Developments in a Concept of Causality", Journal of Econometrics, Vol. 39, 199-211.

Gujarati, D. 2004. “Basic Econometrics”, Fourth Edition, McGraw Hill Companies, New York.

Guler, H. and Talasli, A. 2012. "Determinants Of Sovereign Bond Spreads A Comparative Analysis During The Global Financial Crisis”. MPRA Munich Personal RePEc Archive.

Hansen, E. and Zegarra, J. 2016. "Political Risk and Sovereign Spreads in Latin America", Academia Revista Latinoamericana de Administración, Vol. 29 Iss 2 pp. 165 - 180.

Hilscher, J. and Nosbusch, Y. 2010. "Determinants of Sovereign Risk: Macroeconomic Fundamentals and the Pricing of Sovereign Debt", Review of Finance, 14(2), 235-262.

Hund, J. and Lesmond, D.A. 2008. "Liquidity and Credit Risk İn Emerging Debt Markets", Unpubished Working Paper, University of Texas - Austin and Tulane University, New Orleans, 1-48.

Johansen, S. (1988). "Statistical Analysis of Cointegrating Vectors", Journal of Economic Dynamics and Control, 12, 231-254.

Kamin, S. B. and Von Kleist, K. 1999. "The Evolution and Determinants of Emerging Markets Credit Spreads in the 1990”, BIS Working Papers, 68, 1-33.

Krayenbuehl, T. E. 1985. “Country Risk: Assessment and Monitoring”, Lexington Books, Toronto.

Love, J. and Chandra, R. 2005. "Testing Export-led Growth in South Asia", Journal of Economic Studies, Vol: 32, No: 2, 132-145.

Maltritz, D. and Molchanov, A. 2014." Country Credit Risk Determinants With Model Uncertainty", International Review of Economics \& Finance, Volume 29, January 2014, Pages 224-234.

Martell, R. 2008. "Understanding Common Factors in Domestic and International Bond Spreads*", Review of Finance, Vol. 12 No. 2, pp. 365-389.

Matsumura, M. S. and Vicente, J. V. M. 2010. "The Role of Macroeconomic Variables in Sovereign Risk." Emerging Markets Review, 11(3), 229-249.

Min, H.G. 1998. "Determinants of Emerging Market Bond Spreads. Do Economic Fundamentals Matter?", World Bank Policy Research Working Paper, 1899.

Mora, N. 2006. "Sovereign Credit Ratings: Guilty Beyond Reasonable Doubt?", Journal of Banking \& Finance, 30(7), 2041-2062.

Moser, C. 2006. "The Impact of Political Risk on Sovereign Bonds Spreads Evidence From Latin America", Working Paper, University of Mainz, Mainz.

Mpapalika, J. and Malikane, C. 2019. "The determinants of sovereign risk premium in African countries" Journal of Risk and Financial Management, 12(1), 29.

Mulder, C. and Perrelli, R. 2001. "Foreign Currency Credit Ratings for Emerging Market Economies", IMF Working Paper, Nov, WP/01/191.

Nişanc1, M. 2005. "Eşbütünleşme Tekniği İle Türkiye'de Yakıt Talebinin Analizi”, Atatürk Üniversitesi İktisadi ve Ídari Bilimler Fakültesi Dergisi, Sayı: 19, No: 2, 19-30.

Nogués, J. and Grandes, M. 2001. "Country Risk: Economic Policy, Contagions Effect or Political Noise?", Journal of Applied Economics, Vol. IV, No. 1 (May 2001), 125-162.

Olabisi, M. and Stein, H. 2015. "Sovereign Bond İssues: Do African Countries Pay More To Borrow?", Journal of African Trade, 2: 87-109.

Özatay, F. 2007. “Monetary Policy Challenges for Turkey in European Union Accession Process”, in: Basç1, E., von Hagen, J., Togan, S. (Eds.), Macroeconomic Policies for EU Accession, Edward Elgar.

Özatay, F., Özmen, E. and Şahinbeyoğlu, G. 2009, "Emerging Market Sovereign Spreads, Global Financial Conditions and US Macroeconomic News", Economic Modelling, Vol. 26 No. 2, pp. 526-531.

Rocha, K. and Garcia, F. A. A. 2004. "The Term Structure of Sovereign Spreads in Emerging Markets: a Calibration Approach for Structural Models", IPEA Press, Brazil.

Rojas, A. and Jaque, F. 2003. "Determinants of the Chilean Sovereign Spread: Is it Purely Fundamentals?", Documentos de Trabajo, Banco Central de Chile.

Rowland, P. and Torres, J. (2004), "Determinants of Spreads and Credit Worthiness for Emerging Market Debt: A Panel Data Study", Banco de la República de Colombia, Borradores de Economía, No: 295.

Rozada, M.G. and Yeyati, E. L. 2008. "Global Factors and Emerging Market Spreads," Economic Journal, Vol. 118, Issue 533, 1917-1936.

Sgherri, S. and Zoli, E. 2009. "Euro Area Sovereign Risk During the Crisis", IMF Working Papers, 1-23.

Sy, A. N. (2002). "Emerging Market Bond Spreads and Sovereign Credit Ratings: Reconciling Market Views with Economic Fundamentals", Emerging Markets Review, 3(4), 380-408. 
Şahinöz, S. and Gönenç, R. 2011. "Determinants of Credit Ratings, Sovereign Bond Spreads and Real Interest Rates in Emerging Markets" Iktisat Isletme ve Finans, 26(305), 09-35.

Varlık, N. and Gebeşoğlu, F. 2018. "The Macroeconomic Effects Of Sovereign Risk Premium Shock: A Case Study For Turkey", Yönetim ve Ekonomi Araştırmaları Dergisi, Cilt: 16, Sayı: 2, 236-246.

Varlık, S. (2017). "Ülke Risk Primi Şokunun Bankacılık Sisteminin Sağlamlığına Etkisi: SVAR Modeli Çerçevesinde Türkiye Örneği”", Sosyoekonomi, 25(33), 103-126.

Weigel, D.D. and Gemmill, G. 2006, "What Drives Credit Risk in Emerging Markets? The Roles of Country Fundamentals and Market Co-Movements", Journal of International Money and Finance, Vol. 25 No. 3, pp. 476-502. 